\title{
The Effects of Play-based Reality Therapy Program with Parent Education on Reduced Risk of Smartphone Addiction in Children
}

\author{
Jiyeong Park ${ }^{1}$, Se Young Kim² \\ Myongwoo Institute Clinical Psychology, Seoul, Korea ${ }^{1}$ \\ Department of Christian Counseling, Baekseok University, Cheonan, Korea ${ }^{2}$ \\ 부모교육을 병행한 놀이중심 현실치료상담 프로그램이 아동의 스마트폰 \\ 중독 위험성 감소에 미치는 효과 \\ 박지영 ${ }^{1}$ 김세영 ${ }^{2}$ \\ 명우임상심리연구소, 백석대학교 기독교상담학전공 ${ }^{2}$
}

Objective: The purpose of this study was to examine the effect of play-based reality therapy program on children's self-control, mother-child relationship, and the risk of smartphone addiction.

Methods: The subjects of this study were 18 mother-child pairs who complained of difficulty in their relationship. Subjects were sampled from children found to have a potential risk of smartphone addiction, as assessed by the smartphone addiction proneness scale, and were divided into an experimental group $(\mathrm{N}=8)$ and a control group $(\mathrm{N}=8)$. The play-based reality therapy program was applied to the children for a total of 16 sessions, twice a week, 50 minutes per session, and parent education was applied to the mothers for a total of 8 sessions, once a week, 90 minutes per session. Results: First, play-based reality therapy program with parent education had a positive effect on the children's self-control. Second, play-based reality therapy program with parent education caused positive changes in the subjects' mother-child relationship. Finally, play-based reality therapy program with parent education positively improved the use of smartphone in the children with a risk of smartphone addiction.

Conclusion: This study designed a play-based reality therapy program with parent education and proved that the program had positive effects for children with a risk of smartphone addiction and their mothers. Further, by executing parent education for the mothers of children with a risk of smartphone addiction, this study is meaningful in sustaining the therapeutic effect observed in children and in preventing smartphone addiction.

Keywords: smartphone addiction, play-based reality therapy program, parent education

\footnotetext{
서론

스마트폰은 사용자 중심의 다양한 어플리케이션과 컨텐츠 제

Corresponding Author: Se Young Kim, Department of Christian Counseling, Baekseok University, 76, Munam-ro, Dongman-gu, Cheonan, Chungnam, Korea

E-mail: seykim@bu.ac.kr
}

공으로 현대인의 생활에 편리함을 제공한다. 그러나 이면으로 다양한 사회적 문제를 양산하기도 하는데, 스마트폰 사용 대 상자의 저연령화 및 그에 따른 아동. 청소년 스마트폰 중독 문

(C)The Korean Association of Child Studies

This is an Open Access article distributed under the terms of the Creative Commons Attribution Non-Commercial License (http:// creativecommons.org/licenses/by-nc/4.0) which permits unrestricted noncommercial use, distribution, and reproduction in any medium, provided the original work is properly cited. 
제 등이 이에 해당한다(Korea Internet \& Security Agency [KISA], 2013; National Information Agency [NIA], 2011; Oh, 2014).

스마트폰 중독은 스마트폰의 과도한 사용으로 삶에 부정적 인 결과가 있음에도 불구하고 통제력을 상실하여 스마트폰 사 용을 지속하며, 이에 따라 금단, 내성, 가상세계지향성, 일상 생활장애와 같은 문제가 발생하는 상태를 말한다(NIA, 2011). 그리고 위험 정도에 따라, 고위험군, 잠재적 위험군, 일반 사용 자군으로 분류된다(NIA, 2011). 고위험군은 스마트폰 사용자 가운데 중독 위험이 가장 높은 집단으로, 스마트폰 사용으로 인하여 일상생활에서 심각한 장애를 경험하고 스스로를 중독 이라고 느낀다. 잠재적 위험군은 중독 위험성이 높은 집단으 로 고위험군 사용자만큼 스마트폰을 많이 사용하는 것은 아니 나 과도한 스마트폰 사용으로 인해 일상생활에 어려움을 갖고 있음에도, 이에 대한 문제인식이 없어 고위험군으로 발전할 가능성이 높은 집단이다. 마지막으로 일반 사용자군은 스마트 폰을 건전하게 활용하고 있는 집단이다. NIA (2011)가 아동을 대상으로 실시한 조사에서 아동의 스마트폰 사용 고위험군의 비율은 2011년 2.2\%에서 2013년 2.4\%로 크게 변화하지 않은 반면, 잠재적 위험군은 2011년 9.3\%에서 2013년 23.1\%로 급 증한 것으로 나타났다. 이는 스마트폰 중독 위험성이 높은 아 동의 비율이 급격이 증가하고 있음을 의미하는 것으로, 아동 의 스마트폰 중독에 대한 예방 및 대책 마련의 필요성이 요구 된다.

선행연구에 따르면 스마트폰 중독은 취약한 자기통제력 (B. Kim,, Ko, \& Choi, 2013), 부모-자녀 관계 문제(B. Kim et al., 2013; Oh, 2014), 통제적이거나 강압적인 어머니의 양육태도

(B. Kim \& Choi, 2013) 등과 밀접한 관련이 있는 것으로 보고 된다. 이에 본 연구에서는 아동의 자기통제력과 모-자녀 관계 향상을 바탕으로 스마트폰 중독 위험성을 감소시키는 중재 프 로그램을 구성하고 효과를 검증함으로써 아동의 건강한 성장, 발달을 지원하는데 적용될 수 있는 실용적 자료를 마련하고자 한다.

스마트폰 중독이 인터넷과 휴대폰의 기능이 결합되면서 새 롭게 만들어진 개념(NIA, 2011)임을 고려하여, 기존에 보고된 인터넷 및 휴대폰 중독과 관련된 중재 연구의 경향을 살펴보 면, 주로 동기강화치료, 인지행동치료, 현실치료상담 등 인지 및 행동적 요소가 강조된 개입의 효과성이 높게 평가되고 있 다(H. Kim \& Kim, 2006). 스마트폰 중독을 직접적으로 다룬 경우 역시 중학생(Jeong, Yu, \& Nam, 2014), 고등학생(Seong, 2015)을 대상으로 자기통제 훈련을 중심으로 효과를 입증한 연구들이 보고된다. 이러한 근거를 바탕으로 본 연구에서는
현실치료상담을 기반으로 스마트폰 중독 위험성을 감소시킬 수 있는 프로그램을 구성하고자 한다.

현실치료상담은 스마트폰 중독 잠재적 위험군 아동에게 타 인의 욕구를 방해하지 않으면서 자신의 욕구를 적절한 행동으 로 충족시키고, 보다 책임 있는 행동을 선택하도록 제안한다 (Glasser, 2003). 또한 아동은 자신의 바람과 전행동을 탐색하는 현실치료상담의 과정 가운데 자신의 삶에 대한 통제력을 형성 할 수 있으므로, 현실치료상담은 스마트폰 중독 잠재적 위험군 아동을 위한 효과적인 접근방법이 될 수 있을 것으로 사료된다.

그러나 기존의 현실치료상담 접근의 선행연구들을 살펴보 면, 대부분 청소년 및 성인을 위한 심리교육과 활동지 중심 프 로그램으로 파악된다(H. Lee \& Ahn, 2002). 아동의 인지적 발 달수준을 고려할 때 이러한 형태의 프로그램은 청소년 및 성 인만큼의 효과를 기대하기 어려운 것이 사실이다. 따라서 아 동을 대상으로 프로그램을 진행할 경우에는, 효과성 제고를 위해 연령과 발달에 적합한 활동을 제시할 필요가 있을 것이 다. 이에 본 연구에서는 스마트폰 중독 잠재적 위험군 아동에 대한 보다 효과적인 중재를 위해 놀이를 활용하고자 한다.

아동을 대상으로 하는 집단에서 놀이는 자신의 감정을 자 유롭게 표현할 수 있도록 돕는 의사소통 수단으로 치료에 저 항적인 아동들에게도 친근한 매체이다(Landreth, 1993). 놀이 그 자체만으로도 아동들은 흥미와 내적 동기를 경험하며, 일 상의 욕구를 해소하고 정서적 통제감을 느낄 수 있다(S. Kim, 2017). 특히 상담 동기가 낮고 치료에 저항적인 태도를 보이는 스마트폰 중독 잠재적 위험군 아동들의 저항을 줄이면서, 흥 미와 재미를 느끼도록 하는데 놀이는 무엇보다 유익하다.

또한 아동기의 놀이는 학령 전기와 달리 보다 더 논리적이 며 개인보다는 집단에 초점을 두는 사회적인 경향을 보인다 (Rubin, Bukowski, Parker, 2006). 따라서 이 시기의 아동들을 대 상으로 집단 속에서 놀이 과정을 제공하는 것은 아동의 발달 과정에 부합하며 치료 효과를 증진시켜 줄 것으로 기대된다. 종합하면, 놀이중심 현실치료상담 집단프로그램은 놀이를 통 해 아동에게 현실치료상담의 이론적 개념에 대한 학습을 용이 하게 하며, 집단 놀이 과정 속에서 자신의 선택에 대한 책임감 과 자기평가의 기회를 제공함으로써 아동의 자기통제력을 향 상시키도록 도울 수 있을 것으로 본다.

한편 아동을 대상으로 하는 치료적 개입에서 부모교육은 필수적인데(Killough-McGuire \& McGuire, 2001), 특히 스마트 폰 중독 위험성이 있는 아동에게 부모교육을 통한 접근은 중 요한 요소이다. 아동의 스마트폰 중독 문제는 개인적, 사회적 요인이 복잡하게 얽혀있으며, 근본적인 개선 및 유지를 위해 
서는 다측면적 접근이 함께 고려될 필요가 있기 때문이다.

이와 관련한 선행연구들을 살펴보면, 국가청소년위원회에 서 인터넷 게임 중독 아동을 대상으로 치료 캠프를 실시하고 추적 조사한 결과 부모의 지속적인 관심이 이루어지지 않고 방치된 자녀는 다시 중독에 빠지게 되거나, 캠프 이후 강압적 으로 인터넷 사용을 금지하여 반발심에 더 중독에 빠지게 되 었다는 사례를 보고한바 있다(S. Kim, 2008). 즉 아동에게만 치 료적 접근을 하게 되는 경우 아동이 치료를 통해 집단 내에서 는 자신의 문제를 인식하고 행동을 변화시키려는 의지를 갖게 되더라도, 가정으로 돌아가 어머니로부터 스마트폰 사용과 관 련된 부적절한 피드백과 환경에 노출되면 지속적인 효과를 기 대하기 어려워질 수 있다는 것이다. 이러한 맥락에서 스마트 폰 중독 잠재적 위험군 아동의 어머니를 대상으로, 아동의 심 리적 특성을 이해하고 스마트폰 중독을 적절하게 조절하도록 돕는 방법을 배울 수 있는 부모교육의 필요성이 제기된다.

이에 본 연구에서는 아동에 대한 직접적인 개입과 함께 부 모교육을 병행하여, 아동의 스마트폰 중독 위험성 감소에 보 다 효과적으로 기여할 수 있는 프로그램을 구성하고자 한다. 이를 위해 스마트폰 중독 위험성 아동 어머니를 대상으로 민 주적인 부모-자녀 관계를 바탕으로 자신의 부모양육태도를 개선하고, 아동의 책임감과 통제력을 길러주며 모-자녀 의사 소통을 개선시킬 수 있도록 돕는 STEP 부모교육(K. Lee \& Lee, 2010)을 실시하고자 하며, 여기에 CHANGE (H. Lee \& Shim, 2006) 전략을 접목시켜 스마트폰 중독 위험성 아동의 스 마트폰 사용을 감소시키고자 한다.

정리하면 본 연구는 스마트폰 중독 위험성이 높은 잠재적 위험군 아동과 그 부모에게 부모교육을 병행한 놀이중심 현실 치료상담 프로그램을 실시하고 효과성을 검증함으로써 아동 교육, 복지 및 상담 현장에 적용할 수 있는 유용한 자료를 마련 하고자 한다. 이상의 연구목적을 위해 설정한 연구문제는 다 음과 같다.

\section{연구문제 1}

부모교육을 병행한 놀이중심 현실치료상담 프로그램은 스마 트폰 중독 잠재적 위험군 아동의 자기 통제력 향상에 효과가 있는가?

\section{연구문제 2}

부모교육을 병행한 놀이중심 현실치료상담 프로그램은 스마 트폰 중독 잠재적 위험군 아동의 모-자녀 관계 향상에 효과가 있는가?

\section{연구문제 3}

부모교육을 병행한 놀이중심 현실치료상담 프로그램은 스마 트폰 중독 잠재적 위험군 아동의 스마트폰 중독 위험성 감소 에 효과가 있는가?

\section{연구방법}

\section{연구대상}

본 연구의 대상은 서울지역 초등학교 및 아동청소년센터의 스 마트폰을 보유하고 있는 4-6학년 아동과 그 어머니 16쌍이다. 연구대상은 초등학교와 아동청소년센터에서의 모집 공고를 통한 1차 편의표집, 스마트폰 중독 자가진단 척도( $\mathrm{S}$ 척도)를 실 시하여 잠재적 위험군에 해당하는 아동을 선별하는 2 차 표집, 이후 어머니 면접을 통해 모-자녀 관계에 어려움을 호소하며 연구 참여에 동의하는 모-자녀 쌍을 최종 연구대상으로 선정 하는 3 차 과정을 통해 표집 하였다. 이렇게 연구에 참여한 16 명의 아동과 어머니는 무선배정을 통해 실험집단과 통제집단 에 각각 8쌍씩 배정되었으며, 통제집단 대상자들에게는 연구 과정 종결 후 해당 프로그램을 실시할 것을 약속하였다.

연구대상의 일반적인 특성을 간략히 살펴보면, 실험집단 의 아동은 초등학교 4학년 2명(25.0\%), 5 학년과 6 학년 각 3 명 (37.5\%)이었으며, 통제집단은 4학년 3명(37.5\%), 5학년 2명 (25.0\%), 6학년 3명(37.5\%)으로 구성되었다. 성별은 실험집 단 남아 7명 $(87.5 \%)$, 여아 1명(12.5\%), 통제집단은 남아 6명 (75.0\%), 여아 2명(25.0\%)이었다.

\section{프로그램}

\section{구성, 목표 및 내용}

아동의 스마트폰 중독 위험성을 감소시키기 위해 본 연구에 서는 목표 수립 및 이론 정립, 프로그램 예비구성, 예비프로그 램 실시 및 수정·보완, 본 프로그램 구성의 단계를 거쳐 총 16 회기의 아동대상 놀이중심 현실치료상담 프로그램과, 총 8 회 기의 어머니 대상 부모교육 프로그램을 구성하였다. 이 과정 에서 아동학 박사 2 인, 현실치료상담 전문가 2 인, 부모교육 및 놀이치료 전문가 2 인의 내용타당도 검증이 이루어졌다.

프로그램의 세부목표는 다음과 같다. 첫째, 스마트폰 중독 잠재적 위험군 아동의 자기통제력을 강화시킨다. 자기통제력 
Table 1

Contents of Play-Based Reality Therapy Program

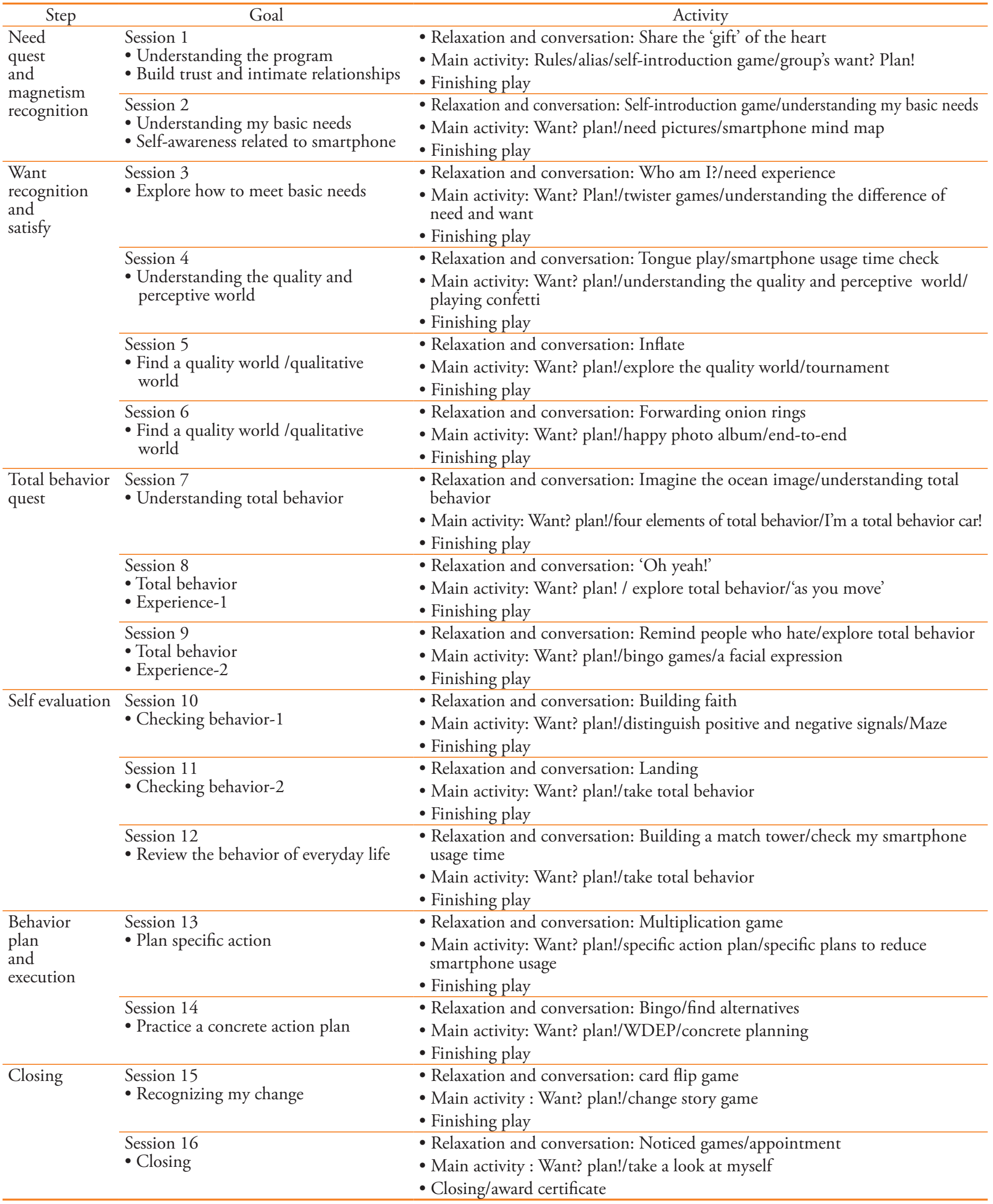


Table 2

Contents of Parent Education Program

\begin{tabular}{|c|c|c|}
\hline Step & Goal & Activity \\
\hline \multirow[t]{3}{*}{$\begin{array}{l}\text { Children } \\
\text { and self- } \\
\text { understanding }\end{array}$} & $\begin{array}{l}\text { Session } 1 \\
\text { - Understanding children and parents }\end{array}$ & $\begin{array}{l}\text { - Build confidence and intimacy-share the 'gift' of the heart } \\
\text { - Understand the need and purpose of parent education } \\
\text { - Understanding of addiction, overuse and understanding of parent-child } \\
\text { relationship and addiction } \\
\text { - Understanding my child } \\
\text { - Understanding myself }\end{array}$ \\
\hline & $\begin{array}{l}\text { Session } 2 \\
\text { - Understanding beliefs and emotions }\end{array}$ & $\begin{array}{l}\text { - Understanding the four goals of wrong behavior } \\
\text { - Understanding the process of forming beliefs and emotions } \\
\text { - Changing beliefs and emotions } \\
\text { - Encourage } \\
\text { - Understanding your own values }\end{array}$ \\
\hline & $\begin{array}{l}\text { Session } 3 \\
\text { - Bring my child's container }\end{array}$ & $\begin{array}{l}\text { - What can i do to raise my child's self-esteem? } \\
\text { - Acquire a variety of encouragement skills } \\
\text { - Encourage myself }\end{array}$ \\
\hline \multirow[t]{4}{*}{ Communication } & $\begin{array}{l}\text { Session } 4 \\
\text { - Make a positive conversation-1 }\end{array}$ & $\begin{array}{l}\text { - Reflective listening and I-message communication } \\
\text { - Become a good audience } \\
\text { - How can I tell my child to listen well? }\end{array}$ \\
\hline & $\begin{array}{l}\text { Session } 5 \\
\text { - Make a positive conversation-2 }\end{array}$ & $\begin{array}{l}\text { - How can we solve the problem together? } \\
\text { - Give my child a choice }\end{array}$ \\
\hline & $\begin{array}{l}\text { Session } 6 \\
\text { - Discipline reasonably }\end{array}$ & $\begin{array}{l}\text { - Using logical results } \\
\text { - Understand the difference between punishment and discipline } \\
\text { - What is the way to raise self-control for my child? }\end{array}$ \\
\hline & $\begin{array}{l}\text { Session } 7 \\
\text { - Change! }\end{array}$ & $\begin{array}{l}\text { - Learning strategy skills of change } \\
\text { - Applying strategy of change }\end{array}$ \\
\hline Closing & $\begin{array}{l}\text { Session } 8 \\
\text { - Going forward }\end{array}$ & - Review the skills \\
\hline
\end{tabular}

은 생활 전반에서 자신에 대해 긍정적으로 생각하면서 자신의 행동을 조절하고 규칙적인 생활을 유지할 수 있게 하는 요인 으로서 스마트폰 중독에 빠질 위험성을 낮춰주는 역할을 한다 (H. Lee \& Ahn, 2002). 자기통제력이 취약한 경우, 아동은 스 마트폰이라는 매체 사용 시 통제력을 상실하면서 중독 경험으 로 발전할 가능성이 높다(G. Lee, 2001). 이에 자기통제력을 강 화시켜줌으로써 일시적인 충동이나 즉각적인 만족을 충족시 키고자 하는 욕구를 지연시킬 수 있게 돕는 것이 필요하다. 둘 째, 스마트폰 중독 잠재적 위험군 아동과 어머니의 긍정적인 모-자녀 관계 형성을 돕는다. 스마트폰 중독 잠재적 위험군 아 동의 어머니는 아동을 적절히 통제하지 못하거나 스마트폰 사 용에 과도하게 허용적이거나 무관심한 태도를 보임으로써 아 동의 스마트폰 중독을 부추기는 결과를 낳는다. 따라서 스마 트폰 중독 잠재적 위험군 아동의 어머니를 대상으로 아동을 적절히 통제하고 민주적인 방식으로 훈육할 수 있는 구체적 인 양육기술과 의사소통 기술을 교육하여 부모양육태도를 긍 정적으로 변화시킬 수 있도록 돕는다. 셋째, 스마트폰 중독 잠
재적 위험군 아동의 스마트폰 중독 위험성을 감소시킨다. 스 마트폰 중독 잠재적 위험군 아동은 필요 이상으로 스마트폰을 사용하는 시간이 증가하고, 집착하게 되는 등 중독으로의 발 전 가능성을 가지고 있으나, 이에 대한 인식이 부족하다. 따라 서 아동이 스마트폰 중독 위험성을 깨닫고, 스스로 스마트폰 사용을 조절하여 계획적으로 사용할 수 있도록 돕는 중재가 필요하다. 이상의 세부 목표 달성을 위해 구성된 프로그램의 회기별 목표 및 활동내용은 Table 1과 Table 2로 제시하였다.

$$
\text { 치료적 요인 }
$$

놀이중심 현실치료상담 프로그램 본 연구의 놀이중심 현실 치료상담 프로그램은 현실치료상담의 RWDEP-system에 따 른 단계로 구성하였다. 첫째, 욕구탐색 단계는 아동이 원하는 것이 무엇인지 탐색하는 단계로 관계 형성 및 욕구 탐색에 목 표를 두었다(Wubbolding, 2007). 이 단계는 욕구탐색 뿐만 아 니라 집단원 간 신뢰감과 친밀감을 쌓는 것과 긍정적 분위기 
를 형성하는 것이 중요하기 때문에, 도입과 탐색 단계에 적합 하며 대인관계적 초점을 촉진시킬 수 있는 자기소개 놀이들을 사용한다(Landreth, 2012; Sweeney \& Homeyer, 1999).

둘째, 바람 인식 및 충족 단계에서는 아동이 자신의 욕구 를 충족시키기 위해 어떠한 방법을 취하고 있는지와 충족시 키지 못하고 있는 욕구를 알아보기 위해 바람(want)을 인식하 는 단계이다. 이 때 집단놀이치료의 탐색 단계 및 초기 성장 단 계에 적합한 트위스터 게임을 활용하였다(Landreth, 2012). 현 실치료상담에서는 이 단계에서 '행복의 책'을 만들면서 아동 들이 자신의 ‘바람' 목록을 작성하도록 하는데, 이를 '트위스 터 게임'에 접목하여 '나의 욕구-바람 트위스터 게임', '바람 찾 기 토너먼트', 'CYL'과 같은 놀이 활동으로 구성하여 실시하였 다. 이는 네 가지 색깔과 욕구를 대응시켜 서로의 욕구를 시각 화한다는 점에서 아동 자신이 자신의 욕구를 인식하고 진정한 바람이 무엇인지 찾아내는 데 유용한 활동이다. 또한 아동의 ‘좋은 세계'를 시각화하기 위해 콜라쥬 작업을 활용하는데, 이 를 ‘행복사진첩 콜라쥬’라고 명명한다. 이 과정에서 아동은 자 신의 진정한 바람이 무엇인지 찾게 된다. 이 과정을 통해 아동 은 자신의 욕구 중 충족되지 못한 욕구를 구분할 수 있게 된다. 이때 밝혀진 채워지지 않은 욕구나 바람은 아동 행동의 원동 력이 된다(Wubbolding, 2007).

셋째, 행동탐색 단계는 원하는 것을 얻기 위해 특정 상황에 서 아동이 어떤 행동을 선택하는지 탐색하는 단계이다. 이 단 계에서 아동은 자신이 시간을 어떻게 보내는지에 대해 전행 동 관점으로 탐색한다(Wubbolding, 2007). 여기서는 눈을 감 고 이미지를 떠올리는 이완 활동을 적용하여 '좋은 세계'를 구 체화한 후, 전행동 자동차, 행동체계를 보다 쉽게 이해할 수 있 도록 구성된 '나는야, 전행동 자동차', '전행동 자동차 게임'과 같은 놀이 활동과 감정을 보여주는 놀이 활동(Landreth, 2012) 을 실시하였다. 이러한 활동을 통해 아동들은 전행동의 네 가 지 요소 중 ‘활동하기'와 ‘생각하기' 요소가 비교적 변화시키기 쉬우며, 이를 통해 자신의 행동변화를 가져올 수 있음을 이해 할 수 있다. 또한, 이러한 일련의 과정은 아동으로 하여금 행동 은 자신이 선택하는 것이라는 것을 알려주며, 다음의 행동 변 화 과정을 이끌어낸다.

넷째, 자기평가 단계는 아동 스스로 자기 행동선택을 평가 하고 새로운 대안과 방법을 찾아가기 위한 단계로 욕구를 충 족시키기 위해 현재 자신이 하고 있는 행동에 대해 평가하는 단계이다. 이를 위해서는 놀이 과정을 통해 아동이 자신의 욕 구 및 바람을 확인하고, 그에 맞는 행동을 선택하여 계획할 수 있는 놀이가 적합하다. 이에 이 단계에서는 믿음 쌓기, 땅따먹
기, 탑 쌓기, 청기백기, 미로, 가라사대와 같은 놀이들을 선택 했다(Landreth, 2012). 이러한 유형의 놀이들은 타인의 행동을 관찰하고, 타인의 지시에 따라 자신의 행동을 조절하는 데 도 움이 되며, 행동표출을 할 수 있도록 구조화된 방법을 제시한 다(Landreth, 2012). 또한, 놀이의 과정 및 결과를 통해 지속적 으로 자신의 행동 및 계획에 대해 평가를 할 수 있으며, 그 결 과 자기조절력을 향상시킬 수 있다.

다섯째, 행동계획 및 실행 단계는 욕구를 충족시킬 수 있는 책임감 있고 효과적인 행동을 모색하고, 행동을 실행하는 단 계이다. 이 단계는 바람 인식 및 충족, 행동탐색, 자기평가 과 정을 거쳐 이루어진 결과에 따라 아동이 쉽게 변화시킬 수 있 는 활동하기 요소를 중심으로 아동의 성취 욕구를 충족시킬 수 있는 구체적이고 실천 가능한 계획을 수립하도록 돕는다. 이를 위해 조절력과 계획력, 협동력을 발휘할 수 있는 '산가지 쌓기 게임'이나 ‘단체 지뢰 빙고 활동'을 활동계획 전과 후로 나누어 진행하여, 스스로 계획 전후를 비교해봄으로써 행동 계획의 필요성을 인식하고 문제해결력을 증진시킬 수 있도록 했다. 이 때 사용되는 놀이는 자기평가 단계에서 사용된 놀이 와 비슷한 맥락으로 자신을 조절하는 데 도움을 주는 놀이들 로 구성하였지만, 이 단계에서는 행동계획 전후로 살펴봄으로 써 행동 계획의 중요성을 강조하고자 하였다. 이러한 일련의 단계를 통해 아동은 욕구탐색부터 행동 계획 및 실행까지 일 상생활에서 수시로 적용시킬 수 있으며, 타인의 욕구를 방해 하지 않고 자신의 욕구를 충족시킬 수 있는 적절한 방법으로 책임감 있는 행동을 실천할 수 있다(Glasser, 1998).

마지막은 종결 단계로 자신의 변화 인식을 도모하고 지금까 지의 변화를 일상생활로 일반화시키는 단계이다. 이 단계는 자 신의 욕구를 충족시킴과 동시에 타인의 욕구를 방해하지 않으 면서, 이전의 행동보다 더 만족스러운 결과를 제공하는 대안 행 동을 선택하여(Glasser, 1998) 자신의 달라진 모습을 확인하는 것을 돕고 자신이 정한 계획을 실행하겠다고 약속을 재확인하 는 단계이다. 이를 위해 집단원 간 '손가락 게임', 본인 스스로를 위한 ‘손가락 칭찬 활동', ‘변화 릴레이 이야기 게임’ 등을 선택 하였는데, 이는 서로의 변화에 대해 축하해주는 기회를 제공함 으로써(Landreth, 2012) 아동으로 하여금 자신의 변화된 모습을 자신뿐만 아니라 타인을 통해서도 재확인하게 한다. 이를 통해 프로그램에 참여한 아동은 스스로 선택한 계획을 실천할 수 있 다는 자신감을 얻고, '나는 할 수 있고, 하겠다!라는 태도로 자 신의 삶을 책임져야 한다는 것을 다시 확인하게 된다.

부모교육 본 연구에서는 어머니의 부모양육태도와 모-자녀 
관계 개선을 위한 훈련에 앞서 스마트폰 중독 잠재적 위험군 아동에 대한 이해를 돕고자 스마트폰 중독 위험성 아동의 특 성 및 심리적 반응, 과다사용 과정, 중독의 특성 등에 대한 교 육을 진행하였다. 이후 아동의 잘못된 행동의 4 가지 목표에 대 해 이해하기, 격려하기, 반영적 경청, 나-전달법, 대안탐색, 선 택권 주기와 같은 의사소통 훈련, 그리고 합리적인 훈육 방식 으로 크게 3가지를 중심으로 구성하였다(Dinkmeyer \& Mckay, 1983). 이와 더불어 스마트폰 중독을 조절하기 위한 구체적인 방법을 습득할 수 있도록 H. Lee와 Shim (2006)의 CHANGE 전략을 추가 구성하였다. 이렇듯 본 프로그램에서 부모교육의 구체적인 치료적 요인은 다음의 4 가지로 나누어볼 수 있다.

첫째, 아동의 잘못된 행동의 4 가지 목표는 '모든 행동에는 사회적인 목적이 있다'는 것을 전제로 한 STEP의 기본 개념 이다. 스마트폰 중독 위험성 아동의 어머니는 아동의 스마트 폰 사용 시간이나 사용 이유에 대해 이해하지 못하고 부정적 인 것으로만 인식함으로써 강압적으로 스마트폰 사용을 제지 하는 등 부적절한 양육행동을 보인다. 스마트폰 중독 위험성 아동은 친구 관계를 형성하기 위해 스마트폰의 소셜 네트워크 기능을 사용하기도 하고, 스트레스를 해소하기 위해 스마트폰 을 사용하기도 하는 등 스마트폰을 사용하는 이유나 목적이 다양하다. 이렇듯 스마트폰 사용의 이유와 목적이 다양함에도 불구하고 모는 스마트폰을 부정적인 것으로만 인식함으로써 아동에 대한 이해 없이 일방적인 제한을 하게 되고, 이는 스마 트폰 중독 위험성 아동과의 갈등을 야기하게 된다. 본 연구에 서는 스마트폰 중독 위험성 아동 어머니로 하여금 아동의 욕 구에 대해 이해하는 것을 목표로 스마트폰 중독 위험성 아동 이 스마트폰을 사용하는 상황을 파악하고, 그 상황에 '잘못된 행동의 4 가지 목표'를 적용해보도록 하였다. 이러한 아동에 대 한 이해를 바탕으로 모 자신의 행동에 대한 이면의 목표도 파 악하여 아동과 모에 대해 보다 잘 이해할 수 있도록 하였다.

둘째, 의사소통 훈련은 격려하기, 반영적 경청, 나-전달법, 대안탐색, 선택권 주기 등의 기술로 이루어져 있다. 의사소 통 훈련은 모-자녀 간 원만한 관계를 형성하기 위해 중요하다 (Dinkmeyer \& Mckay, 1983). 아동은 자아존중감이 낮을수록 모-자녀 관계가 부정적일수록 스마트폰 중독에 빠질 확률이 높으며(G. Lee, 2001), 모-자녀 관계는 아동의 스마트폰 중독이 심각해질수록 부정적으로 변화할 가능성이 높아진다. 모는 아 동의 스마트폰 중독에 대한 불만이 높아짐에 따라 명령, 제지, 협박 등의 부정적인 양육 기술을 사용하게 된다. 따라서 본 연 구에서는 명령, 제지, 협박, 강요 등의 양육 기술은 오히려 아 동에게 역효과를 일으킨다는 사실을 이해하고 부정적인 양육
기술 대신 '격려하기' 습관을 기를 수 있도록 하였다. '반영적 경청'은 말 이면에 숨은 감정에 귀를 기울여 듣는 기술로, 이 를 통해 스마트폰 중독 위험성 아동의 어머니는 아동의 감정 을 이해하고, 자녀를 존중하는 태도를 전달하면서 아동의 가 치감을 향상시킬 수 있고 아동은 어머니로부터 이해받고 있음 을 느끼게 된다. 그 결과 스마트폰 중독 위험성 아동은 스스로 자신의 감정을 파악하고 자연스럽게 자신의 감정에 대해 말할 수 있으며, 일상생활에서 자신의 감정을 분석하여 스스로 문 제에 대한 해결책을 강구해내는 방법을 터득할 수 있다. 또한, 반영적 경청은 자녀에게 '안돼'라는 말을 전달하기에 유용한 듣기 기술이기 때문에 이를 적용한다면 스마트폰 중독 위험 성 아동의 감정 이면의 이유를 전달함과 동시에 스마트폰 사 용에 대한 제지를 도울 수 있다. 스마트폰 중독 위험성 아동과 어머니가 겪는 다양한 문제 상황에 대해 알아보고, 이 중 문제 소유자가 아동에게 있는 상황에서 반영적 경청 기술을 적용하 고 연습해보았다. '나-전달법'은 문제 상황에서 아동이 아니라 어머니에게 초점을 두며 어머니 자신의 느낌만을 전달함으로 써 아동을 비난하거나 판단하지 않는 방법이다. 본 프로그램 에서는 이를 숙지하고 스마트폰 중독 위험성 아동과 어머니가 일상생활에서 자주 경험하는 다양한 사례들에 적용해보았으 며, 나-전달법을 활용하여 아동에게 선택권을 줌으로써 아동 스스로 대안을 탐색할 수 있도록 연습해보았다. '대안탐색과 선택하기'는 문제의 소유자가 누구인지에 상관없이 사용할 수 있는 기술로 대화를 통한 문제해결방법이다. 이를 통해 스마 트폰 사용시간, 스마트폰 사용 시간대 등을 아동과 협력하여 해결할 수 있는 방안을 찾는데 도움이 되고자 하였다.

셋째, 합리적인 훈육 방식은 아동에게 한계를 설정하고, 그 한계 내에서 책임 있는 선택을 할 수 있도록 자연적·논리적 보상체계의 훈육방법이다. 스마트폰 중독 잠재적 위험군 아동 의 경우, 미래의 만족이나 목표보다 즉흥적인 욕구를 충족시 키는 것을 추구하다보니 매체의 중독적 사용에 빠지게 되는 경우가 많다(G. Lee, 2001). 그 결과 스마트폰 중독 위험성 아 동들은 숙제를 미룬다거나 학원에 가야할 시간에 가지 않는 등 해야 할 일을 제 시간에 하지 않아 모와의 갈등을 야기한다. 이러한 특징 때문에 어머니들은 아동에게 일방적인 제지, 명 령을 하게 되며, 강압적인 방식의 양육방식을 취하게 된다. 반 면, 논리적 결과를 사용한 훈육방법은 현재와 미래의 행동에 관심을 두기 때문에, 아동으로 하여금 자율적으로 결정하도록 기회를 주며, 자기 평가를 할 수 있도록 돕는다. 즉, 논리적 결 과를 이용하여 아동 스스로 자신의 문제를 책임지고 자신의 행동을 조절할 수 있도록 돕는 것이다. 
넷째, CHANGE 전략 기술은 스마트폰 중독 위험성 아동 의 스마트폰 사용에 대한 구체적인 개입 전략으로 구조화된 방법으로 어머니에게 쉽게 이해시킬 수 있다. CHANGE의 앞 글자를 따서 관찰하기(Check), 회고하기(History), 분석하기 (Analysis), 변화 방법 찾기(Negotiation), 목표 세우기(Goal), 효 과 확인하기(Effect)의 6가지 단계로 이루어져 있다. 이 단계는 프로그램의 후반부에 구성함으로써 스마트폰 중독 위험성 아 동의 어머니들이 배운 다양한 의사소통 기술을 접목하면서 단 계를 밟아갈 수 있도록 하였다.

\section{측정도구}

\section{자기통제력}

아동의 자기통제력을 측정하기 위해 Kendall과 Wilcox (1979) 의 자기통제평정척도(Self-Control Rating Scale [SCRC])를 Shim (2004)이 초등학생용으로 수정한 자기보고식 문항을 사 용하였다. 대표 문항은 '나는 누가 지켜보지 않아도 정해진 규 칙이나 지시를 잘 따른다.'로 아동학 박사 3 인의 내용타당도 검증 과정을 통해 타당도 관련 증거를 확보하였다. 총 20 문항 의 Likert식 5점 척도로 점수가 높을수록 자기통제력이 높음을 의미하며, Cronbach's $\alpha$ 는 .80이었다.

\section{모-자녀 관계}

아동이 지각하는 모-자녀 관계를 측정하기 위해 Choi (2006)가 제작한 한국형 부모-자녀 관계 척도(Parent-Child Relationship Instrument [PRI])를 사용하였다. 친밀, 헌신, 존경, 엄격의 4요인 으로 구성되어 있는 Likert식 5점 척도로, 친밀, 헌신, 존경은 점 수가 높을수록, 엄격은 점수가 낮을수록 아동이 지각하는 모자녀 관계가 긍정적임을 의미한다. 각각의 대표문항을 살펴보 면, 친밀은 "어머니는 나를 가장 잘 아는 친한 친구 같은 분이시 다.", 헌신은 "어머니는 나에 대해 헌신적이시다.", 존경은 "나는 나의 어머니가 자랑스럽다.", 엄격은 "어머니는 나를 엄하게 다 루셔서 무섭게 느껴진다.”이다. 아동학 박사 3 인의 내용타당도 검증결과 모든 문항은 각각의 요인에 대한 내용을 적절히 반영 하는 것으로 확인되었으며, Cronbach's $\alpha$ 는 .65 .75로 나타났다.

$$
\text { 스마트폰 중독 }
$$

NIA (2011)의 아동용 스마트폰 중독 자가진단 척도를 사용하
였다. 총 15문항 Likert식 4점 척도로 “스마트폰 사용시간을 줄 이려고 해보았지만 실패한다.”와 같은 문항으로 구성되어있 다. 점수가 높을수록 스마트폰 중독 위험이 높은 것을 의미하 며, 규준에 따라, 고위험군(원점수 45점 이상), 잠재적 위험군 (원점수 42-44점), 일반 사용자군(원점수 41점 이하)으로 분류 할 수 있다. 이 연구에서의 Cronbach's $\alpha$ 는 .73이었으며, 아동학 박사 3 인의 내용타당도 검증결과 모든 문항은 아동의 스마트 폰 중독에 대한 내용을 적절히 반영하는 것으로 확인되었다.

\section{연구설계 및 절차}

본 연구는 사전 사후 검사 통제집단 설계로, 실험집단에는 부 모교육을 병행한 놀이중심 현실치료상담 프로그램을 실시하 고, 통제집단에는 어떠한 처치도 하지 않았다. 그리고 프로그 램의 효과를 검증하기 위해 프로그램 실시 전후, 실험집단과 통제집단의 연구대상 아동에게 동일하게 자기통제력, 모-자 녀 관계 및 스마트폰 중독 검사를 실시하였다.

프로그램은 서울시 소재 해당학교와 아동청소년센터의 협 조 하에 각 기관 내 교실 및 집단치료실에서 진행되었다. 아동 대상의 놀이중심 현실치료상담 프로그램은 주 2회 50 분씩 8 주간, 어머니 대상 부모교육은 동일한 시기에 주1회 90 분씩 8 주간 이루어졌다. 부모교육을 병행한 놀이중심 현실치료상담 프로그램은 아동학 전공 지도교수 1 인, 현실치료상담 전문가 2 인, 부모교육 및 놀이치료 전문가 2 인의 조언을 얻어 프로그 램 진행과정 및 회기별 내용에 대해 검토 받아, 전 회기를 연구 자가 직접 진행하였다. 연구자는 현실치료상담 전문교육과정 을 수료하였으며, 아동가족심리치료분야에서 7년 이상의 아 동상담 및 부모교육 경력을 가진 아동학 박사 수료자이다.

\section{자료분석}

본 연구에서 수집된 자료는 SPSS 18.0 (IBM Co., Armonk, NY) 프로그램을 통해 빈도분석, Mann-Whitney U test, Wilcoxon signed rank test를 실시하였다.

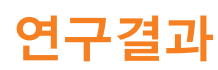

\section{실험집단과 통제집단 간 사전 동질성}

프로그램 실시 전, 실험집단과 통제집단 아동의 자기통제력, 
Table 3

Pre-Homogeneity Verification of Experimental Group and Control Group

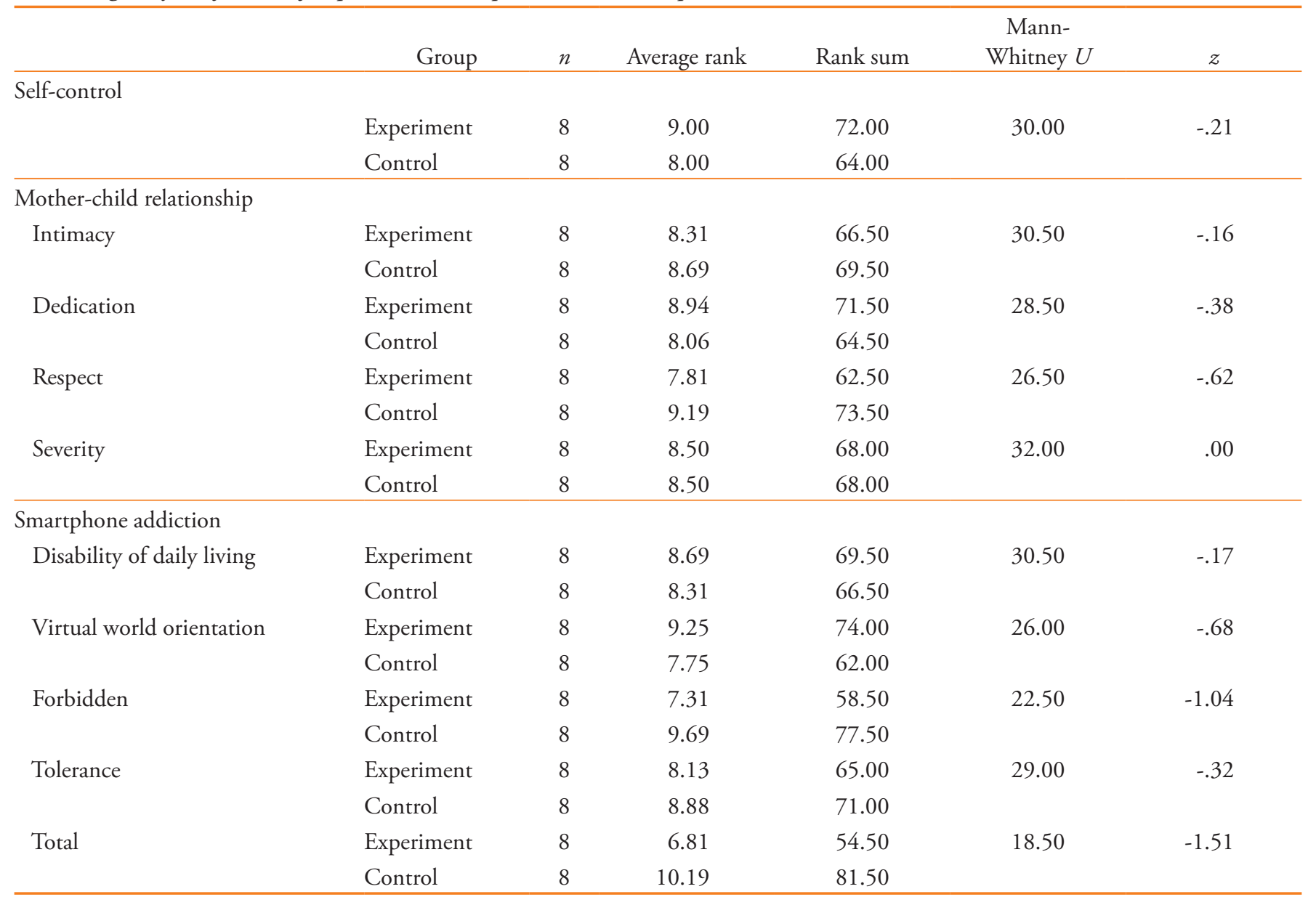

모-자녀 관계 및 스마트폰 중독 위험성 점수에 대해 MannWhitney U test를 실시한 결과, 모든 해당 변인에 대한 두 집단 의 동질성이 확인되었다(Table 3 ).

\section{프로그램 효과 검증}

프로그램의 효과를 검증하고자 실험집단과 통제집단 아동의 자기통제력, 모-자녀 관계 및 스마트폰 중독 위험성의 사전-사 후 점수를 비교하였다. 그 결과를 살펴보면 다음과 같다.

첫째, 실험집단의 자기통제력 점수는 사전에 비해 사후에 유의하게 증가하였다 $(z=-2.37, p<.05)$. 그러나 통제집단은 사 전-사후 점수 간 유의한 차이가 나타나지 않았다.

둘째, 실험집단 아동이 지각하는 모-자녀 관계의 변화를 살 펴보면, 친밀 $(z=-2.23, p<.05)$ 과 헌신 $(z=-2.37, p<.05)$ 의 점 수는 사후 검사에서 유의하게 상승하였으며, 엄격 $(z=-2.39$, $p<.05)$ 점수는 유의하게 감소하였다. 이는 아동이 느끼는 어
머니와의 모-자녀 관계가 개선된 것을 의미하는 것으로, 통제 집단 아동이 지각하는 모-자녀 관계에서는 유의한 차이가 나 타나지 않았다.

셋째, 스마트폰 중독의 모든 하위요인(일상생활 장애: $z=-2.27, p<.05$, 가상세계 지향성: $z=-2.64, p<.01$, 금단: $z=$ -2.33, $p<.05$, 내성: $z=-2.23, p<.05)$ 및 전체 점수 $(z=-2.55$, $p<.05)$ 에서 사전에 비해 사후 점수가 유의하게 감소하였다. 이는 규준에 근거하여 볼 때 잠재적 위험군에서 일반 사용자 군으로 중독 위험성이 감소한 의미 있는 변화였다. 반면 통제 집단은 스마트폰 중독 전체 $(z=-2.52, p<.05)$ 점수와 하위영역 인 내성 $(z=-2.26, p<.05)$ 의 점수가 사후검사에서 오히려 증가 하였다. 이는 통제집단의 스마트폰 중독 정도가 더 심해진 것 을 의미하며, 규준에 준하여 볼 때 잠재적 위험군에서 고위험 군으로 중독 위험성이 높아진 양상이었다.

이상의 결과는 부모교육을 병행한 놀이중심 현실치료상담 프로그램이 아동의 자기통제력 및 모-자녀 관계 향상과 함께, 
Table 4

Pre-Post Score Difference of Experimental Group and Control Group

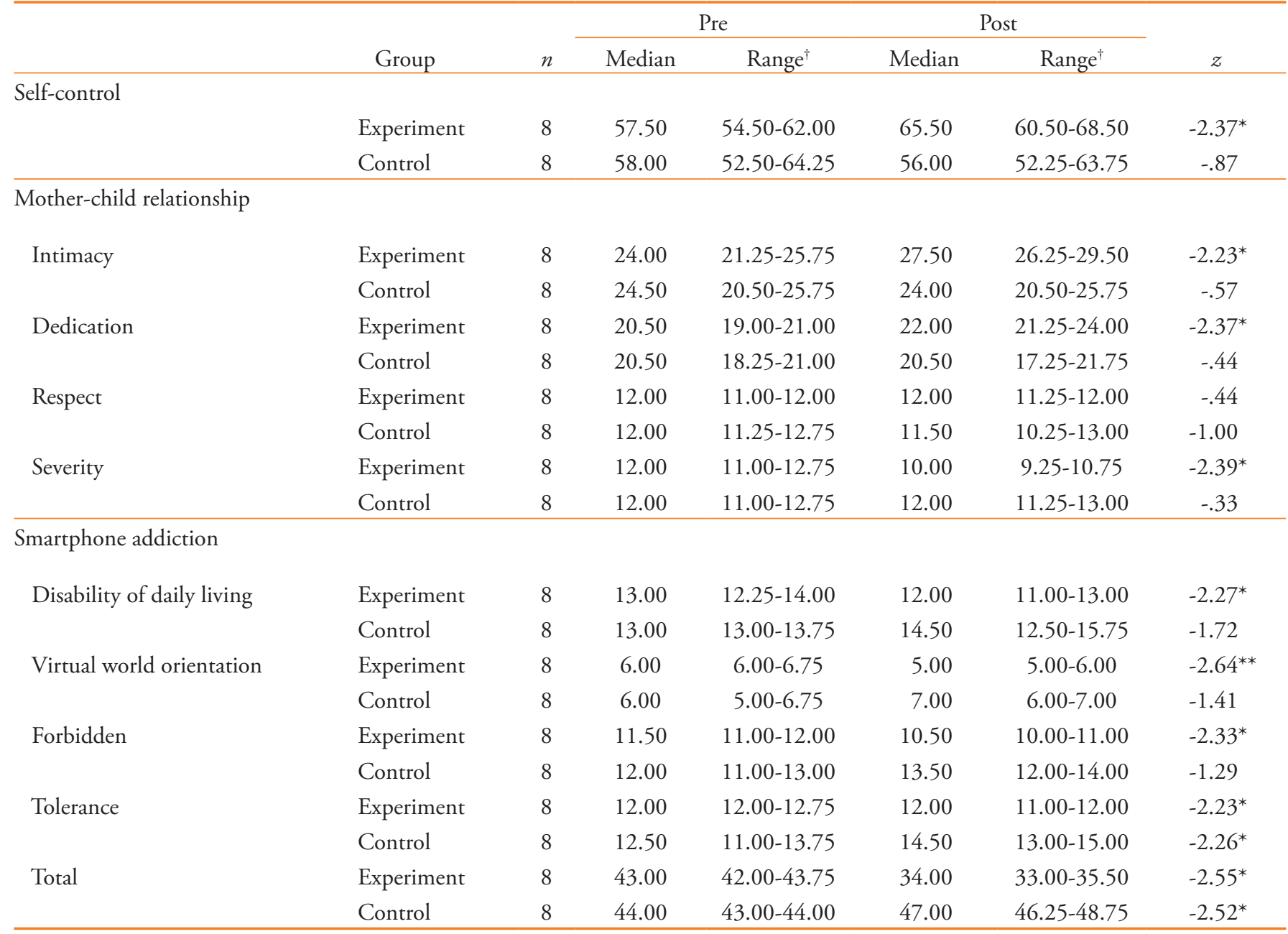

Note. ${ }^{\dagger}$ Quadrant range (25th\% - 75th\%)

${ }^{*} p<.05 .{ }^{* *} p<.01$.

궁극적으로 스마트폰 중독 위험성을 낮추는데 효과가 있음을 의미한다.

\section{논의 및 결론}

이 연구는 아동의 스마트폰 중독 위험성을 감소시키기 위해 부모교육을 병행한 놀이중심 현실치료상담 프로그램을 구성 하고 효과를 검증하는 것을 목적으로 하였다. 이를 위해 사전 사후검사 통제집단 설계로, 실험집단의 스마트폰 중독 잠재적 위험군 아동과 그 어머니에게 각각 놀이중심 현실치료상담 프 로그램과 부모교육을 실시하였다. 그리고 실험집단과 통제집 단 아동의 자기통제력, 긍정적 모-자녀 관계 및 스마트폰 중독
위험성의 변화를 확인하였다.

결과를 정리하고 논의하면 첫째, 부모교육을 병행한 놀이 중심 현실치료상담 프로그램은 스마트폰 중독 잠재적 위험군 아동의 자기통제력 향상에 긍정적인 효과가 있었다. 자기통제 력은 한 개인이 자신의 행동과 감정을 스스로 조절할 수 있는 능력으로 스마트폰 중독 위험성 아동은 자기통제력이 약하다 는 특징을 갖는다(H. Lee \& Ahn, 2002). 그런데 본 프로그램에 서는 스마트폰 중독 잠재적 위험군 아동의 자기통제력이 향상 되었다. 이는 부모교육을 병행한 놀이중심 현실치료상담 프로 그램에서 아동이 자신의 욕구를 인식하고 생각과 행동을 통제 할 수 있도록 꾸준히 개입한 것의 효과로 여겨진다. 현실치료 상담 집단프로그램을 실시했을 때, 내적 통제성이 향상되었다 는 Han (2006)의 연구결과가 이를 뒷받침한다. 
둘째, 부모교육을 병행한 놀이중심 현실치료상담 프로그램 은 스마트폰 중독 잠재적 위험군 아동과 어머니의 모-자녀 의 사소통에 긍정적인 효과가 있었다. 구체적으로 스마트폰 중독 잠재적 위험군 아동은 프로그램 실시 후 어머니를 더욱 친밀 하게 느끼고, 자신을 배려해주고 너그러운 어머니로 인식하는 정도가 높아졌다. 즉 어머니가 아동에게 일관적인 양육방식을 취하도록 개입한 교육과 훈련이 아동이 지각하는 모-자녀 관 계 증진에 긍정적으로 작용한 것으로 평가된다. 어머니는 스 마트폰 중독 잠재적 위험군 아동을 애정적이고 자율적으로 양 육하는 빈도가 높아졌으며, 아동을 강압적으로 통제하고 행동 에 제약을 가하던 태도가 감소하였다. 부모교육에 참여한 어 머니들은 아동에게 잔소리하거나 겁을 주는 방식 대신 자신의 감정을 전달함으로써 긍정적인 양육태도로 변화하였다. 그리 고 이는 아동의 긍정적 정서 강화와 아동 스스로 스마트폰 사 용량을 줄이고자 시도하는 계기로 연결되었다. 이러한 아동들 의 변화 모습은 부모의 양육태도가 긍정적으로 변화하였을 때 초등학생 자녀의 인터넷 중독이 낮아진다는 Jo (2011)의 연구 결과와 일치한다.

한편, 모-자녀 관계 중 존경과 관련된 부분에서는 유의한 차이가 없었다. 존경의 경우 어머니를 존경하고 본받고 싶은 정도 등과 같이 아동의 어머니에 대한 인식을 측정하는 문항 들로 구성되어 있다. 이에 비해 친밀, 헌신, 엄격에 대한 부분 은 아동과 어머니의 직접적인 상호작용 내용에 대한 아동의 지각을 측정하고 있다. 즉, 이러한 결과는 본 연구의 프로그 램이 아동과 어머니의 긍정적 상호작용을 증진하는데 초점 을 두고 있음과 무관하지 않을 것으로 보인다. 또한 어머니의 권위 있음에 대한 인식보다 따뜻하고 수용적인 모-자녀 관계 가 아동의 자기통제력 향상을 통한 스마트폰 중독 위험성 감 소에 보다 직접적으로 관계되는 변인일 가능성도 생각해 볼 수 있다.

셋째, 결과적으로 부모교육을 병행한 놀이중심 현실치료상 담 프로그램은 스마트폰 중독 잠재적 위험군 아동의 스마트 폰 사용 조절에 효과가 있었다. 특히 스마트폰 중독 자가진단 척도의 규준 상 프로그램 참여 전 잠재적 위험군이었던 아동 들이 프로그램 참여 후 일반 사용자군 집단에 속하는 변화 양 상을 보였다. 이는 부모교육을 병행한 놀이중심 현실치료상담 프로그램이 스마트폰으로 인한 아동의 일상생활 장애 완화 및 가상세계 지향 정도의 감소에 효과적이었음을 의미한다. 아동 의 금단현상과 내성 또한 유의하게 감소되었는데, 이러한 결 과는 프로그램 과정에서 아동이 스마트폰 사용정도에 문제의 식을 느끼고 변화하려는 동기가 높아진 것이 영향을 미쳤을
것으로 보인다. 또한 자신의 욕구를 탐색하고, 다른 대안책을 만들어 실행에 옮기는 등의 행동변화가 긍정적 영향을 미친 것(G. Lee, 2001)으로 생각해 볼 수 있다. 이는 인터넷 중독 아 동에게 현실치료상담 집단프로그램을 실시했을 때 인터넷 사 용 정도가 완화되었다는 H. Kim과 Kim (2006)의 연구결과를 지지하며, 내담자가 스스로 문제의식을 느꼈을 때 행동적 변 화가 나타날 수 있다는 Jang과 Sin (2003)의 이론과 맥을 같이 한다. 또한 놀이를 활용한 치료 프로그램이 인터넷 중독 개선 에 효과적이었다는 S. Lee와 Lee (2008)의 연구결과와도 일치 한다.

본 연구의 결과를 토대로 후속연구를 위해 제언하면 다음 과 같다. 첫째, 본 연구는 스마트폰 중독 잠재적 위험군 아동 과 어머니의 모-자녀 관계의 변화를 측정하기 위해 척도에 의 한 사전-사후 평가만을 제시하였다. 모-자녀 관계의 행동관찰 이나 의사소통 변화 과정을 통해 질적 결과의 보완이 이루어 지지 않았다는 점에서 한계가 있다. 둘째, 본 연구에서는 스 마트폰 중독 잠재적 위험군 아동과 어머니를 대상으로 부모 교육을 병행한 놀이중심 현실치료상담 프로그램을 실시한 실험집단과 통제집단으로 구성하여 효과를 검증하였다. 그 러나 놀이중심 현실치료상담 프로그램만 개입한 집단과 부 모교육을 병행한 놀이중심 현실치료상담 프로그램을 개입 한 집단 간의 효과성 차이를 살펴보기 위한 비교연구가 필요 하다고 판단된다. 셋째, 본 연구에서는 연스마트폰 중독 잠재 적 위험군 아동 16 명 중 여아가 3 명으로, 실험집단 8 명 중 한 명만 여아로 구성되었다. 이는 여아에 비해 남아의 스마트폰 중독 사용률이 더 높다는 통계적 보고들과 같은 양상이나, 스 마트폰 중독 아동의 성별에 대한 데이터는 부족한 실정이기 에 후속 연구에서는 성별의 비율을 고려한 연구가 이루어지 기를 기대한다. 넷째, 본 연구에서는 프로그램의 개입 효과를 유지하고 확인하기 위한 추후 검사를 실시하지 못하였는데, 추후 검사를 통해 프로그램 효과의 지속성을 살펴보기 위한 후속 연구가 필요하다.

본 연구는 아동의 스마트폰 중독 위험성에 대한 예방적, 치 료적 개입 방안을 모색하는 차원에서 부모교육을 병행한 놀이 중심 현실치료상담 프로그램을 구성하였다. 그리고 프로그램 이 스마트폰 중독 잠재적 위험군 아동의 자기통제력 및 모-자 녀관계의 긍정적 변화를 통해, 궁극적으로 스마트폰 중독 위 험성을 의미 있게 감소시키는데 효과가 있음을 경험적으로 입 증하였다. 이에 아동의 스마트폰 중독 관련 중재방안 모색에 활용될 수 있는 실용적 자료 및 근거를 마련하였다는데 이 연 구의 의의를 찾을 수 있다. 


\section{Notes}

This article is based on the doctoral dissertation of the first author and was presented as a poster at the 2017 Annual Fall Conference of the Korean Association of Child Studies.

\section{Conflict of Interest}

No potential conflict of interest relevant to this article was reported.

\section{References}

\section{In English}

Dinkmeyer, D., \& Mckay, G. D. (1983). The parent's guide: STEP/ Teen, systematic training for effective parenting of teens. New York: American Guidance Service.

Glasser, W. (1998). Choice theory: A new psychology of personal freedom (1st ed.). New York: Harper \& Row Publishers.

Glasser, W. (2003). Warning: Psychiatry can be hazardous to your mental health. New York: HarperCollins.

Kendall, P. C., \& Wilcox, L. E. (1979). Self-control in children: Development of a rating scale. Journal of Consulting \& Clinical Psychology, 47(6), 1020-1029. doi:10.1037/0022006X.47.6.1020

Killough-McGuire, D. K., \& McGuire, D. E. (2001). Linking parents to play therapy: A practical guide with applications, inerventions, and case studies. New York: Routledge.

Landreth, G. L. (1993). Child-centered play therapy. Elementary School Guidance \& Counseling, 28(1), 17-29.

Landreth, G. L. (2012). Play therapy: The art of the relationship (3rd ed.). New York: Routledge.

Rubin, K., Bukowski, W., \& Parker, J. (2006). Peer interaction and social competence. In W. Damon \& R. M. Lerner (Eds.), Handbook of child psychology (6th ed, Vol. 3.). New York: Wiley.

Sweeney, D. S., \& Homeyer, L. E. (1999). Group play therapy. In D. S. Sweeney \& L. E. Homeyer (Eds.), The handbook of group play therapy: How to do it, how it works, whom it's best for (pp. 3-14). San Francisco, CA: Jossey-Bass.

Wubbolding, R. E. (2007). Glasser quality school. Group Dynamics: Theory, Research, And Practice, 11(4), 253-261.

\section{In Korean}

Choi, I. J. (2006). Hangukhyeong bumo-janyeogwangye cheokdo gaebal mit tadanghwa yeongu[한국형 부모-자녀관계 척 도 개발 및 타당화 연구](Report No. 06-R22). Retrieved from NYPI website:. https://www.nkis.re.kr

Han, H. R. (2006). The effect of group counseling based on reality therapy on the internal control and the school adjustment ability of elementary school children (master's thesis). Retrieved from www.riss.kr/link?id=T10942162/

Jang, J.-H., \& Sin, H.-J. (2003). The effect of a protection program for adolescent excessive use of internet. Korean Journal of Counseling and Psychotherapy, 15(4), 651-572.

Jeong, S.-R., Yu, H.-K., \& Nam, S.-I. (2014). Development of a group counseling program to prevent addiction to smartphones in a potential risk group of middle school students. Korea Journal of Counseling, 15(3), 1145-1162. doi:10.15703/ kjc.15.3.201406.1145

Jo, H. (2011). The effect of elementary school students' perceived parenting attitude and internet use motives on internet addiction: Self-control as a mediator. Journal of Adolescent Welfare, 13(4), 269-287.

Kim, B. N., \& Choi, H. I. (2013). Effects of study overprotective parent's raising attitudeon university student's smartphoneaddiction: The mediating effects of self-control. Social Science Research Review, 29(1), 1-25.

Kim, B., Ko, E., \& Choi, H. (2013). A study on factors affecting smart-phone addiction in university students: A focus on differences in classifying risk groups. Studies on Korean Youth, 24(3), 67-98.

Kim, H. O., \& Kim, S. H. (2006). The effect of the reality therapy group counseling program on the improvement of self-esteem, internal control, and addictive internet use of the internetaddicted elementary school students. Journal of Educational Research Mokpo National University, 18(1), 11-22.

Kim, S. H. (2008). Internet jungdok, jibjungchiryocampeuro gochyeosseoyo[인터넷 중독, 집중치료캠프로 고쳤어요]. Seoul: Dongailbo. Retrieved March 10, 2018, from http:// news.donga.com/3/all/20080616/8590558/1

Kim, S. Y. (2017). A case study on child-centered play therapy for a child with adhd and odd: Focusing on the change of play theme at stage. Korean Journal of Child Studies, 38(4), 103115. doi:10.5723/kjcs.2017.38.4.103

Korea Internet \& Security Agency. (2013). 2102nyeon habangi smartphoneiyongsiltaejosa yoyakbogoseo[2012년 하반기 스 마트폰이용실태조사 요약보고서]. Retrieved from KISA website: https://isis.kisa.or.kr/

Lee, G. (2001). Study on internet addiction of adolescent (Doctoral dissertation). Retrieved from http://www.riss.kr/ link?id=T8156536/

Lee, H.-C., \& Ahn, C.-Y. (2002). A study on the development and effectiveness of cognitive-behavioral therapy for internet addiction. Korean Journal of Health Psychology, 7(3), 463- 
486.

Lee, H. C., \& Shim, K. S. (2006). Internet jungdok wanjeonjeongbok[인터 넷 중독 완전정복]. Seoul: Sigmapress.

Lee, K. W., \& Lee, I. W. (2010). Dangsindo yuneunghan sangdamjaga doel su itta[당신도 유능한 부모가 될 수 있 다]. Seoul: Changjisa.

Lee, S.-M. \& Lee, S.-H. (2008). The effects of play based self control training group program on the internet addiction levels and self control ability of middle school students. The Journal of Play Therapy, 12(2), 55-74.

National Information Agency (2011). Development of Korean smartphone addiction proneness scale for youth and adults. Seoul: NIA.

Oh, J. (2014). A study on the major factors to teenagers' addiction to smart-phone. Journal of Public Welfare Administration, 24(1), 47-76.

Seong, M. A. (2015). Development of a group counseling program to prevent the smartphone addiction in a potential risk group of high school students (Master's thesis). Retrieved from http://
www.riss.kr/link?id=T13717347

Shim, R.-H. (2004). Relationship between internet addiction and self-efficacy, self-control, parent-child relationship and peer relationship (Master's thesis). Retrieved from http://www. riss.kr/link?id=T9181672

\section{ORCID}

Jiyeong Park

https://orcid.org/0000-0002-4552-5316

Se Young Kim https://orcid.org/0000-0002-4318-8838

Received April 30, 2018

Revision received May 30, 2018

Accepted June 6, 2018 